\title{
Comparison Analysis of Start-Up Company Liquidity Before and After the Covid-19 Pandemic
}

\author{
*Friska Sipayung ${ }^{1}$, Liasta Ginting ${ }^{2}$, Magdalena L. L. Sibarani ${ }^{3}$ \\ ${ }^{1}$ Faculty of Economics and Business, Universitas Sumatera Utara, Medan, Indonesia \\ ${ }^{2}$ Faculty of Economics and Business, Universitas Sumatera Utara, Medan, Indonesia \\ ${ }^{3}$ Faculty of Economics and Business, Universitas Sumatera Utara, Medan, Indonesia \\ *Corresponding author. E-mail: friska@usu.ac.id
}

\begin{abstract}
The enormous challenges faced by companies today are various problems and technological advances. One of the problems is pandemic-19. During this pandemic, companies across multiple business fields were affected. Even the Covid-19 pandemic resulted in a very significant decrease in the turnover of small and medium-sized businesses. Likewise, startup companies face several possible risks to their liquidity. The study's goal was to investigate whether there were significant differences in the liquidity of startup companies before and after the Covid-19 pandemic. The parameters used to assess and compare the company's liquidity are by analyzing financial statements using the Current Ratio. Data are processed with the Paired Sample t-tests and Wilcoxon Signed Ranks Test, using SPSS/Predictive Analysis. The results showed that the liquidity of startup companies was different between before and after the Covid-19 Pandemic. In real terms, Pandemic Covid-19 can reduce startup companies' liquidity.
\end{abstract}

Keywords: Financial Ratio, Liquidity, and Current Ratio.

\section{INTRODUCTION}

Business organizations in this era are getting immense challenges with various problems and technological advances with the present difficulties and the progress that has been made. It means that every business must compete and improve its competitiveness. To stay up with the times and survive in an ever-evolving world of technology, information, and communication developments. As a form of organization, startup companies also face problems and challenges as outlined. Like other companies, startup companies also have specific goals that they want to achieve to meet the interests of their members. Liquidity depicts a company's cash position and ability to pay off or fulfill debt obligations according to the agreed-upon maturity date. A liquidity assessment is required to determine the company's capacity to meet short-term obligations.

The Covid-19 pandemic initially surfaced when the World Health Organization (WHO) received a report from China on December 31, 2019, stating that an unknown virus had caused an outbreak in the port city of Wuhan. The attack expanded so quickly to numerous countries that it became a global pandemic in the following two weeks. In Indonesia, the government designated the coronavirus pandemic as a national disaster on Saturday, March 14, 2020, and Indonesia entered a non-natural disaster emergency. Soon after the corona was declared a national disaster, the government urged people to isolate themselves and reduce gathering and outdoor activities. Some companies allow their workers to work from home. These precautions made the Indonesian economy and even the world economy slow significantly. The question arises, how is the impact of this pandemic on the liquidity of startup companies?

The overall impact of Covid-19 on the financial performance of Islamic banking in Indonesia, as evaluated by the CAR, ROA, NPM, and FDR ratios, indicates no substantial variance in economic performance, according to [1]. This suggests that Islamic banking in Indonesia can continue to operate even if there is a pandemic. In contrast, according to [2], the average sales of microbusiness products are declining at $50 \%$, indicating a significant drop in sales. $40 \%$ of micro-businesses have gone out of business due to capital shortages. Approximately 
$62.84 \%$ of micro-businesses experienced a decrease in sales profits and capital difficulties, and the rest is a figure reported as having gone out of business.

The research on SMEs showed that SMEs are the types of companies most affected by the covid19 pandemic, including automotive industries, steel industry, electrical equipment, textile industry, crafts, heavy equipment, tourism [3].

Based on this phenomenon, the author was interested in conducting a study titled "Comparative Analysis of Start-up Companies Before and After the Covid 19 Pandemic". The research was conducted on startup company PT Bukalapak.com.Tbk, one of the Indonesia Most Admired Company Award 2020. The problem in this study is formulated as follows: Is the liquidity of startup companies measured from the Current Ratio (CR) different between before and after the Covid-19 Pandemic?

\section{LITERATURE REVIEW}

\subsection{Financial Ratio}

According to [4], a financial ratio is a method of comparing data in financial statements. Financial ratios help analyze economic conditions and assess management performance in a company. Financial statements detail the company's activity throughout a given period. The numbers represent the actions that have been completed. A comparison can be made between one component in one financial statement and another or between elements in different financial statements. If we compare a part to another, these figures will become more significant. After a comparison, a corporation's financial situation for a given period can be determined. The numbers being compared can then be from one time or multiple eras.

According to [5], a financial ratio is a statistic derived from the outcomes of comparisons between two financial statement accounts that have a relevant and substantial link. According to [6], this financial ratio is particularly significant when conducting an economic study of a corporation. Short- and medium-term investors are often more concerned with the company's capacity to pay enough dividends and short-term financial situations. The information can be obtained more straightforwardly by calculating the financial ratios according to the desires. That financial ratio is a mathematical calculation comparing specific postings or components in financial statements. That link to later and demonstrates changes in a company's financial status.
Some sorts of financial ratios can assess a company's economic performance. Each financial ratio has a distinct purpose, unique usefulness, and particular significance. The results of each measured ratio are then evaluated to be used to make decisions [4]. Liquidity ratios, which characterize a company's ability to satisfy short-term obligations, and solvency ratios, which assess the amount to which a company's assets are backed by debt, can be deduced from the description. The activity ratio assesses resource usage efficiency, whereas the growth ratio represents its ability to maintain its financial position. Valuation ratios measure a company's management's ability to increase its market value over its investment costs. Some of the percentages that are frequently employed, according to [5], are:

1) A company's ability to settle short-term liabilities is described by its liquidity ratio.

2) The Solvency Ratio measures a company's capacity to pay long-term obligations or liabilities if liquidated.

3) Rentability Ratio: This metric describes a company's ability to generate profits using its available resources and capabilities.

4) Leverage Ratio: The leverage ratio describes the relationship between a company's debt and its capital and assets. This ratio can show how much of a company's funding comes from debt or outside sources than its capital capacity.

5) Activity Ratio: Describes the activities that the corporation engages in when conducting business, including sales, purchasing, and other activities.

6) Growth Ratio: Indicates how much a company's posts have grown from year to year.

7) Market-Based Ratio: This is a frequently utilized ratio in the capital market that shows the situation/state of the company's capital market accomplishments.

8) This ratio indicates the level of productivity of the unit or activity assessed, for example, the percentage of employees to sales and the cost per employee.

From some of these statements, it can be concluded that different financial ratios vary according to their respective usefulness and kind of company in economics. In this study, researchers used the liquidity ratio. Analysis of financial statements will not be meaningful if there is no comparison. The data comparison of absolute financial ratios exists so that calculations can be done to the selected ratio. We can see the difference in the numbers highlighted with the comparison 
data, whether it increases or declines in the previous period. The comparison data required according to [4] is as follows:

1) The figures in each component of the financial statements include total current assets with current debt and comprehensive support with a total obligation-the level of sales with profits, and so on.

2) The figures in each type of financial statement include total assets on the balance sheet with sales in the income statement.

3) The year of each financial statement for several periods

4) Target ratios that the company has budgeted as guidelines for achieving objectives

5) Industry standards used for the same industry

6) The financial ratio of competitors in nearby, similar businesses is used as a reference material to assess financial ratios obtained in addition to existing industry standards.

These comparison figures can be drawn from financial statements made or other sources. Specifically for competitor ratios can be obtained from financial statements made and published or from marketing intelligence. Then, for the target, each balance is predetermined. Meanwhile, the average industry ratio can be obtained from institutions authorized to issue; for example, banking can be obtained from Bank Indonesia.

According to [6], the benefits that can be taken with the use of financial ratios are:

1) Financial ratio analysis is an excellent instrument for evaluating a company's performance and accomplishments

2) Financial ratio analysis is an excellent tool for managers to guide when planning.

3) Creditors can benefit from financial ratio analysis. It can calculate the potential risks to ensure the continuation of interest payments and the loan's return on principle.

4) Financial ratio analysis can evaluate the organization's stakeholders.

\subsection{Liquidity Ratio}

Firms and investors frequently use this ratio to determine their ability to meet their obligations [4]. These are only temporary duties. Short-term commitments include paying utility bills, employee salaries, or maturing debts. On the other hand, some businesses cannot pay their debts on time.

Using the premise that the company lacks the financial resources to pay past-due bills. This means that if a business is invoiced, it will pay the obligation, even if it is past late. If the company is billed, it will satisfy (pay) the obligation significantly if the debt is matured. While short-term liquidity is commonly referred to, according to [6], liquidity is a picture of a company's ability to satisfy short-term obligations easily and on time. According to the definition, the liquidity ratio measures a company's ability to meet short-term obligations easily and on time.

The liquidity ratio calculation is sufficient to benefit the company's numerous stakeholders. The most interested parties are the company's owner and management, who want to evaluate the company's success. Outside parties with interests in the company include creditors and fund providers, such as banks, distributors, and suppliers. As a result, calculating the liquidity ratio is beneficial to the corporation and outsiders. According to [4], the following are the objectives and benefits of the liquidity ratio results:

1) To assess or compare the company's current preparations to its working capital

2) To figure out how much money is available to pay down debts

3) In terms of financial and debt management, as a tool for predicting needs.

4) To compare multiple periods to analyze the company's financial state and liquidity situation over time.

5) Examine the current liquidity ratio and use it as a trigger for management to improve its performance.

There are several types of ratios that each have their purpose and purpose. The kinds of liquidity ratio measurements are as follows:

1) The current ratio (CR) is a metric for comparing existing assets to current liabilities. The current ratio to the benchmark of 200 percent $(2: 1)$ is usually used as a good enough or appropriate criterion in practice. Growing promptly at the time of total billing. The current ratio is calculated using the following formula:

Current Ratio $=\frac{\text { Current Asset }}{\text { Current Liability }}$

2) The quick ratio measures a company's capacity to meet or pay short-term obligations or debt using current assets alone, without accounting for inventory value. This is done because, compared to other existing assets, the preparation is thought to require more profit to be cashed 
if the corporation requires fast funds to satisfy its obligations. The following is the formula for calculating a quick ratio:

Quick Ratio $=\frac{\text { Current Asset }- \text { Inventory }}{\text { Current Liability }}$

3) The cash ratio is a metric for determining how much money is available to pay off debts. The availability of cash or cash equivalents, such as checking or savings accounts in banks, might indicate the availability of money (which can be withdrawn at any time). The following is the formula for calculating the cash ratio:

Cash Ratio $=\frac{\text { Cash Equivalent }}{\text { Current Liability }}$

4) The Cash Turnover Ratio (cash turnover) measures a company's working capital, which is used to pay invoices and fund sales. This ratio determines the cash available to pay bills (debts) and sales-related expenses. The formula for calculating cash turnover ratios is as follows:

Cash Turnover Ratio

$$
=\frac{\text { Net Sales }}{\text { Net Working Capital }}
$$

5) Inventory to Net Working Capital is a ratio of inventory to networking capital that compares the number of existing preparations to the company's working capital. The working capital consists of a reduction between current assets and current debt. The following is the formula for calculating Inventory to Net Working Capital:

Inventory NWC Ratio

$$
=\frac{\text { Inventory }}{\text { Current Asset }- \text { Current Liability }}
$$

\subsection{Conceptual Framework of Research}

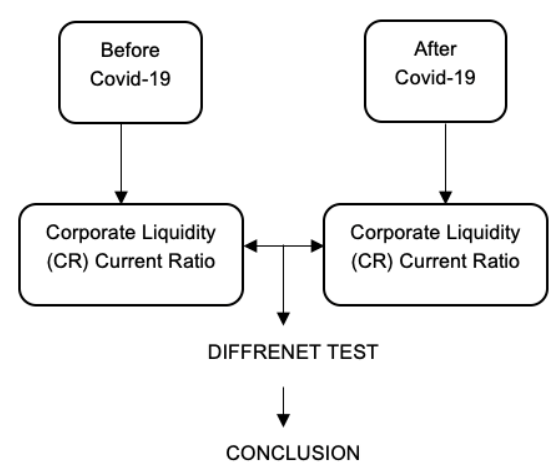

Figure 1. Conceptual Framework of Research

\subsection{Research Hypothesis}

According to [1], the impact of Covid-19 on the financial performance of Islamic banking in Indonesia, as evaluated by the CAR, ROA, NPM, and FDR ratios, demonstrates no substantial change in economic performance. This suggests that Islamic banking in Indonesia can continue to operate even if there is a pandemic. In contrast, according to [2] research [2020], the average sales of microbusiness products are declining at $50 \%$, indicating a significant drop in sales. The following hypotheses are offered in this study:

Ho: The current ratio (CR) of the company does not differentiate between before and after Covid

Ha: The current ratio (CR) of companies differs between before and after Covid

\section{RESEARCH METHODS}

\subsection{Research Design}

This study is a case study. This study will test in detail against an object that is the liquidity of startup companies before and after Covid-19. This research is related to the condition of a company within a particular time. Researchers will compare the company's liquidity before and after Covid-19 using Kolmogorov Smirnov's One Sample analysis method for normality tests, Paired Sample t-tests, and Wilcoxon Signed Ranks Tests for hypothesis tests.

\subsection{Sampling Techniques}

The sampling technique used in this study uses purposive sampling, which is sampling using criteria determined based on the policies of researchers. This study used sampling criteria such as the following:

The financial statements of startup companies, from 2019 to 2020 published in www.IDX.co. id (one year before and after the covid-19 pandemic in the quarter)

Financial accounts for a startup company from 2019 to 2020, including all data and information required for variable measurement and analysis in research hypothesis testing. 


\subsection{Data Collection Techniques}

The method of data collection used in this study is a method of documentation, namely by recording or documenting the data listed on IDX 2019-2020 conducted by taking financial statement data from startup companies.

\subsection{Data Analysis Technique}

With the following processes, descriptive statistics provide an overview or descriptive of a data set based on the mean value, standard deviation, and variants: Calculating the average level (mean), standard deviation, and variants of financial ratios used to measure a company's economic performance. Calculate the difference between before and after the covid-19 pandemic in the company's financial statistics mean (up / down).

\subsection{Hypothesis Test}

This study used a Paired Sample t-test, using SPSS/Predictive Analysis, because this statistical test tool will provide precise results for redistributed populations, requiring normality assumption testing and more conservatively for two discrete distributed people. The study also used the Wilcoxon Signed Ranks Test.

\section{RESULT AND DISCUSSION}

\subsection{Company's Current Ratio Before and After Cov-19}

The Current Ratio was employed to indicate the liquidity ratio in this study. The current balance is a measurement standard commonly used in various industries to assess a company's short-term liquidity while accounting for available assets and liabilities. In other words, the current ratio measures a company's capacity to pay all of its bills on time. This method is used to assess a company's financial health worldwide. The following are the formulas for calculating the current ratio:

Current Ratio $=\frac{\text { Current Asset }}{\text { Current Liability }}$

The Current Ratio (CR) of startup companies is calculated based on the company's financial statements of PT. Bukalapak.com.Tbk - in 2018 until June 2021. The Current Ratio is presented in Table 1.
Table 1. Liquidity Ratio (Current Ratio) PT Bukalapak.com. Tbk Before and After Covid-19

\begin{tabular}{|c|c|c|}
\hline \multirow{8}{*}{$\begin{array}{l}\text { Corporate Liquidity } \\
\text { (Current Ratio) } \\
\text { Before and } \\
\text { After Covid-19 }\end{array}$} & \multicolumn{2}{|c|}{ Current Ratio } \\
\hline & $\begin{array}{c}\text { Before Covid } \\
\text { 2018-2019 }\end{array}$ & $\begin{array}{l}\text { After Covid } \\
2020-2021\end{array}$ \\
\hline & 331.21 & 211.53 \\
\hline & 301.51 & 274.14 \\
\hline & 260.66 & 200.66 \\
\hline & 265.53 & 226.12 \\
\hline & 268.98 & 236.12 \\
\hline & 231.53 & 238.48 \\
\hline Average & 276.57 & 231.17 \\
\hline
\end{tabular}

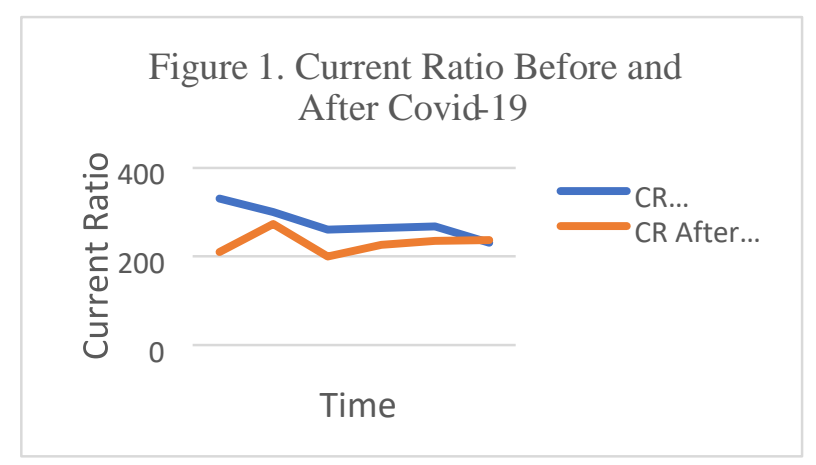

Figure 2. Current Ratio Before and After Covid 19

In general, the Current Ratio of startup companies before and after Covid-19 is relatively good, despite the decline. Table 1 and Figure 1 show that before Covid-19, the company's average current ratio was 276.57\%, and after Covid-19, 231.17\%. A good CR standard is $200 \%$.

\subsection{Data Normality Test}

The Shapiro-Wilk Normality Test is performed to determine the random distribution of a small sample of data. [7] employed data simulations of no more than 50 samples in their seminar articles. The Shapiro-Wilk test is recommended for data samples of less than 50 samples (N50). If the significance value is more significant than 0.05 (sig. > 0.05), the data is said to be regularly distributed.

The Kolmogorov - Smirnov Normality test determines the distribution of random and specific data in a population. Based on the National Institute of Standards and Technology tests, the KolmogorovSmirnov test is suitable for data sizes 20-1000.

The Kolmogorov - Smirnov Normality test determines the distribution of random and specific 
data in a population. Based on the National Institute of Standards and Technology tests, the KolmogorovSmirnov test is suitable for data sizes 20-1000.

However, in general research, Kolmogorov Smirnov testing is still used for data samples with more than 2000 samples $(20 \leq \mathrm{N} \leq 1000)$. The Kolmogorov Smirnov test is indicated for data with more than 50 samples. The data is regularly distributed if the significance values are more than 0.05 (sig. > 0.05)

Table 2. Descriptive Result

\begin{tabular}{|c|c|c|c|c|}
\hline & \multirow{2}{*}{$\frac{\text { Statistic }}{276.5700}$} & \multirow{2}{*}{$\begin{array}{r}\text { Std. Error } \\
14.22293\end{array}$} \\
\hline \multirow{13}{*}{$\begin{array}{l}\text { Current } \\
\text { Ratio } \\
\text { Before }\end{array}$} & \multicolumn{2}{|l|}{ Mean } & & \\
\hline & \multirow{2}{*}{$\begin{array}{l}\text { 95\% Confidence } \\
\text { Interval for } \\
\text { Mean }\end{array}$} & $\begin{array}{l}\text { Lower } \\
\text { Bound }\end{array}$ & 240.0088 & \\
\hline & & $\begin{array}{l}\text { Upper } \\
\text { Bound }\end{array}$ & 313.1312 & \\
\hline & \multicolumn{2}{|c|}{ 5\% Trimmed Mean } & 276.0367 & \\
\hline & \multicolumn{2}{|l|}{ Median } & 267.2550 & \\
\hline & \multicolumn{2}{|l|}{ Variance } & 1213.751 & \\
\hline & \multicolumn{2}{|l|}{ Std. Deviation } & 34.83892 & \\
\hline & \multicolumn{2}{|l|}{ Minimum } & 231.53 & \\
\hline & \multicolumn{2}{|l|}{ Maximum } & 331.21 & \\
\hline & \multicolumn{2}{|l|}{ Range } & 99.68 & \\
\hline & \multicolumn{2}{|c|}{ Interquartile Range } & 55.56 & \\
\hline & \multicolumn{2}{|l|}{ Skewness } & .578 & .845 \\
\hline & \multicolumn{2}{|l|}{ Kurtosis } & .164 & 1.741 \\
\hline \multirow{13}{*}{$\begin{array}{c}\text { Current } \\
\text { Ratio After }\end{array}$} & \multicolumn{2}{|l|}{ Mean } & 231.1750 & 10.43464 \\
\hline & \multirow{2}{*}{$\begin{array}{l}\text { 95\% Confidence } \\
\text { Interval for } \\
\text { Mean }\end{array}$} & $\begin{array}{l}\text { Lower } \\
\text { Bound }\end{array}$ & 204.3519 & \\
\hline & & $\begin{array}{l}\text { Upper } \\
\text { Bound }\end{array}$ & 257.9981 & \\
\hline & \multicolumn{2}{|c|}{ 5\% Trimmed Mean } & 230.4833 & \\
\hline & \multicolumn{2}{|l|}{ Median } & 231.1200 & \\
\hline & \multicolumn{2}{|l|}{ Variance } & 653.290 & \\
\hline & \multicolumn{2}{|l|}{ Std. Deviation } & 25.55954 & \\
\hline & \multicolumn{2}{|l|}{ Minimum } & 200.66 & \\
\hline & \multicolumn{2}{|l|}{ Maximum } & 274.14 & \\
\hline & \multicolumn{2}{|l|}{ Range } & 73.48 & \\
\hline & \multicolumn{2}{|c|}{ Interquartile Range } & 38.58 & \\
\hline & \multicolumn{2}{|l|}{ Skewness } & .785 & .845 \\
\hline & \multicolumn{2}{|l|}{ Kurtosis } & 1.012 & 1.741 \\
\hline
\end{tabular}

Table 3. Tests of Normality 


\begin{tabular}{|l|c|c|c|c|c|c|}
\hline \multirow{2}{*}{} & \multicolumn{3}{|c|}{ Kolmogorov-Smirnov ${ }^{2}$} & \multicolumn{3}{c|}{ Shapiro-Wilk } \\
\cline { 2 - 7 } & Statistic & $\mathrm{df}$ & Sig. & Statistic & $\mathrm{df}$ & Sig. \\
\hline $\begin{array}{l}\text { Current } \\
\text { Ratio Before }\end{array}$ & .253 & 6 & $.200^{*}$ & .948 & 6 & .727 \\
\hline $\begin{array}{l}\text { Current } \\
\text { Ratio After }\end{array}$ & .221 & 6 & $.200^{*}$ & .950 & 6 & .737 \\
\hline *. This is a lower bound of the true significance. \\
\hline \\
a. Lilliefors Significance Correction \\
\hline
\end{tabular}

The data are typically distributed; it qualifies for the use of paired sample t-test. The value of significance ( $p$ ) in the Kolmogorov-Smirnov test is $(\mathrm{p}>0.05)$, indicating that the data is distributed generally according to the Kolmogorov-Smirnov normality test. The Shapiro-Wilk test's significant values $(p)$ are $(p>0.05)$, indicating that the data are generally distributed according to the Shapiro-Wilk normality test.

4.3. Different Test (Paired Sample t-test) Company's Liquidity Before and After Covid-19

Table 4. Paired Samples Statistics

\begin{tabular}{|c|c|c|c|c|c|}
\hline \multicolumn{6}{|c|}{ Paired Samples Statistics } \\
\hline & & Mean & $\mathrm{N}$ & $\begin{array}{c}\text { Std. } \\
\text { Deviation }\end{array}$ & $\begin{array}{c}\text { Std. Error } \\
\text { Mean }\end{array}$ \\
\hline \multirow{2}{*}{$\begin{array}{c}\text { Pair } \\
1\end{array}$} & $\begin{array}{c}\text { Current } \\
\text { Ratio Before }\end{array}$ & 276.5700 & 6 & 34.83892 & 14.22293 \\
\hline & $\begin{array}{c}\text { Current } \\
\text { Ratio After }\end{array}$ & 231.1750 & 6 & 25.55954 & 10.43464 \\
\hline
\end{tabular}

This output shows the results of a statistical summary of both samples or CR data before and after. The value before obtaining the average CR is 276.5700. As for the CR value after processing, the average CR value of 231.1750. The CR value after Covid < CR after Covid can be descriptively stated that there is a difference in the current ratio before and after Covid.
Table 5. Paired Samples Correlations

\begin{tabular}{|c|c|c|c|c|}
\hline \multicolumn{5}{|c|}{ Paired Samples Correlations } \\
\hline \multicolumn{2}{|c|}{} & N & Correlation & Sig. \\
\hline Pair 1 & $\begin{array}{c}\text { Current Ratio Before \& } \\
\text { Current Ratio After }\end{array}$ & 6 & .039 & .942 \\
\hline
\end{tabular}

According to the output values in Table 5, the correlation coefficient is 0.039 with a significant (sig) value of 0.942. Given that Sig. Value. $0.942>$ 0.05 , it may be concluded that there is no association between variables before and following Covid-19. 
Table 6. Paired Samples Test

\begin{tabular}{|c|c|c|c|c|c|c|c|c|c|}
\hline & & & Paire & d Diffe & rences & & $t$ & $d f$ & Sig. (2tailed) \\
\hline & & . & $\begin{array}{l}\text { Std. } \\
\text { Devi } \\
\text { ation }\end{array}$ & $\begin{array}{l}\text { Std. } \\
\text { Error } \\
\text { Mear }\end{array}$ & $\begin{array}{r}\text { Con } \\
\text { Interv } \\
\text { Diff }\end{array}$ & $\begin{array}{l}5 \% \\
\text { fidence } \\
\text { al of the } \\
\text { erence }\end{array}$ & & & \\
\hline & & Mean & & & Lower & Upper & & & \\
\hline & Current & 45.39 & 42.40 & 17.31 & .8974 & 89.892 & 2.6 & 5 & .047 \\
\hline & Ratio & 500 & 145 & 032 & 1 & 59 & 22 & & \\
\hline & Before & & & & & & & & \\
\hline Pair 1 & - & & & & & & & & \\
\hline & Current & & & & & & & & \\
\hline & Ratio & & & & & & & & \\
\hline & After & & & & & & & & \\
\hline
\end{tabular}

There is a difference between the current ratio before and after Covid19 if the probability or sig. (2tailed) value is less than 0.05 , showing that the Covid19 pandemic lowered startup firms' current ratio and vice versa. The Paired Samples Test result indicates the sig value. (2-tailed) by.047. Following that, Asymp. sig. (2-tailed) $0.047<0.05$ is acceptable. This means that the Current Ratio before the Covid epidemic is not the same as the Current Ratio following the Covid pandemic. That is, pandemic covid is capable of lowering the current ratio.

\subsection{Wilcoxon Signed Ranks Test Company's Liquidity Before and After Covid-19}

To complete a different test or comparison of the Current Ratio before and after Covid-19, the Wilcoxon Signed Ranks Test is performed.

Table 7. Wilcoxon Signed Ranks Test.

\begin{tabular}{|c|c|c|c|c|}
\hline \multicolumn{5}{|c|}{ Ranks } \\
\hline & & $\mathrm{N}$ & Mean Rank & Sum of Ranks \\
\hline \multirow{4}{*}{$\begin{array}{l}\text { Current Ratio After } \\
\text { Current Ratio Before }\end{array}$} & Negative Ranks & $5^{a}$ & 04.00 & 20.00 \\
\hline & Positive Ranks & $1^{\mathrm{b}}$ & 01.00 & 01.00 \\
\hline & Ties & $0^{c}$ & & \\
\hline & Total & 6 & & \\
\hline \multicolumn{5}{|c|}{ a. Current Ratio After < Current Ratio Before } \\
\hline \multicolumn{5}{|c|}{ b. Current Ratio After > Current Ratio Before } \\
\hline \multicolumn{5}{|c|}{ c. Current Ratio After = Current Ratio Before } \\
\hline
\end{tabular}

Table 8. Result Test Statistics

\begin{tabular}{|l|r|}
\hline \multicolumn{2}{|c|}{ Test Statistics $^{\mathrm{a}}$} \\
\hline & $\begin{array}{l}\text { Current Ratio After - } \\
\text { Current Ratio Before }\end{array}$ \\
\hline$Z$ & $-1.992^{\mathrm{b}}$ \\
\hline
\end{tabular}

\begin{tabular}{|l|l|}
\hline Asymp. Sig. (2-tailed) & .046 \\
\hline a. Wilcoxon Signed Ranks Test \\
\hline b. Based on positive ranks.
\end{tabular}

According to the Wilcoxon Signed Ranks Test, five ratios fell after the covid pandemic, and one increased. Then there is Asymp. When the Sig. (2- 
tailed) is 0.0460 .05 , Ha is accepted. This indicates that the Current Ratio before the Covid pandemic differs from the Current Ratio following the Covid pandemic. In other words, the covid pandemic has the potential to lower the Current Ratio.

\section{CONCLUSION}

Starting enterprises' current ratio (CR) varies before and after the Covid-19 Pandemic. Pandemic Covid-19 can reduce the liquidity of new enterprises evaluated in actual terms.

On this occasion, we would like to express our deepest gratitude to the research at the Universitas Sumatera Utara. This paper and the research behind it would not have been possible without the excellent support of our university. Who has provided a grant to implement this research through the USU 2021 TALENTA. Hopefully, the Universitas Sumatera Utara will move forward.

\section{ACKNOWLEDGMENT}

On this occasion, the author also expresses his gratitude to the International Conference on Economics, Management and Accounting (2nd ICEMAC 2021) for accepting this article for publication in the 2nd ICEMAC Proceedings. I hope the 2nd ICEMAC can be implemented soon. Thank you.

\section{REFERENCES}

[1] Ilhami and H. Thamrin, "Analisis Dampak Covid 19 Terhadap Kinerja Keuangan Perbankan Syariah Di Indonesia," J. Tabarru' Islam. Bank. Financ., vol. 4, no. 1, pp. 2021, 37-45, doi: 10.25299/jtb.2021.vol4(1).6068.

[2] M. Syamsudin, "Dampak-pandemi-covid19-terhadap-umkm-di-indonesia-HEHYh," Sep. 2020.

[3] R. Rosita, "Pengaruh Pandemi Covid-19 Terhadap Umkm Di Indonesia," J. Lentera Bisnis, vol. 9, no. 2, p. 109, 2020, doi: 10.34127/jrlab.v9i2.380.

[4] Kasmir, Analisis Laporan Keuanagan. Jakarta, 11th ed. Raja Grafindo Persada, 2018.

[5] S. S. Harahap, Analisis Kritis atas Laporan Keuangan, 14th ed. Raja Grafindo Persada, 2018.

[6] I. Fahmi, Analisis Kinerja Keuangan. Bandung: Alfabeta, 2012.

[7] Oktaviani M A and Hari Basuki Notobroto, "Perbandingan Tingkat Konsistensi Normalitas Distribusi Metode KolmogorovSmirnov, Lilliefors, Shapiro-Wilk, dan Skewness-Kurtosis," J. Biometrika dan Kependud., vol. 3, no. 2, pp. 127-135, 2014. 